\title{
PELAKSANAAN DOKUMENTASI KEPERAWATAN BERDASARKAN MODEL POR (PROBLEM ORIENTED RECORD)
}

\author{
Kiki Dwi Febriyanti
}

Kiifeb83@gmail.com

\section{LATAR BELAKANG}

Pendokumentasian merupakan kegiatan pencatatan dan pelaporan yang penting dilakukan oleh perawat karena melalui pencatatan dan pelaporan semua kegiatan perawat akan terdokumentasi dengan baik. Pendokumentasian adalah kegiatan menuliskan data kesehatan sehingga bisa dibaca yang merupakan proses keperawatan sebagai dasar dalam memberi asuhan keperawatan. (Huston, 2008; Heartfield 2008). Hal ini didukung oleh Kozier (2005), pendokumentasian merupakan bukti akuntabilitas tindakan keperawatan yang dilakukan perawat dalam pelayanan keperawatannya terhadap pasien. Perawat juga dituntut untuk menerapkan dokumentasi keperawatan sebagai tanggung jawab profesi dan aspek legal. Kelengkapan dokumentasi keperawatan merupakan salah satu indikator mutu asuhan keperawatan yang diberikan.

Peningkatan mutu pelayanan di rumah sakit harus melibatkan semua unsur, termasuk didalamnya adalah unsur manajer melalui fungsi manajemen yang terdiri dari lima fungsi manajemen menurut Fayol (1908, dalam Stoner, Freeman dan Gilbert, 1996) yaitu planning, organizing, leading, coordinating, and controlling. Sedangkan Gullick (2008) mengemukakan konsep planning, organizing, staffing, directing, coordinating, reporting, budgeting atau dikenal dengan akronim POSDCORB (Schlosser, 2009). Fungsi pencatatan dan pelaporan (reporting) merupakan salah satu fungsi yang berhubungan dengan pelaksanaan pendokumentasian.

Tenaga perawat sebagai salah satu tenaga yang mempunyai kontribusi besar bagi pelayanan kesehatan, mempunyai peranan penting untuk meningkatkan mutu pelayanan kesehatan. Dalam upaya meningkatkan mutu pelayanan kesehatan, seorang perawat harus mampu melaksanakan asuhan keperawatan sesuai standar, yaitu dari mulai pengkajian sampai dengan evaluasi dan yang sangat penting adalah disertai dengan sistem pendokumentasian yang baik. Dokumentasi keperawatan adalah bagian yang penting dari dokumentasi klinis. Oleh karenanya 
diperlukan pembahasan mengenai macammacam pendokumentasian keperawatan

\section{METODE}

metode yang digunakan dalam penulisan ini adalah metode kajian bebas dimana metode ini berwilayah lebih sempit dengan tingkat variasi yang rendah, namun dari penulisan ini dapat berkembang menjadi lebih luas. Metode kajian bebas ini merupakan metode yang dilakukan untuk melakukan penulisan yang dikumpulkan dari beberapa sumber seperti buku teks, buku referensi jurnal dan e-book, dan juga dibandingkan dengan jurnal yang berhubungan dengan "pelaksanaan dokumentasi keperawatan dengan model POR(Problem Oriented Record)". Sehingga pembaca dapat mengerti informasi yang sudah ditulis dan dapat memahami dokumentasi keperawatan dalam melaksanakan asuhan keperawatan di rumah sakit.

\section{HASIL}

Dokumentasi keperawatan adalah suatu catatan yang dapat dibuktikan atau dapat dijadikan bukti dari segala macam tuntutan, yang berisi datalengkap, nyata dan tercatat bukan hanya tentang tingkat kesakitan dari pasien, tetapi juga jenis/type, kualitas dan kuantitas pelayanan kesehatan dalam memenuhi kebutuhan pasien. (Fisbach 1991). Mutu asuhan keperawatan dapat tergambar dari dokumentasi proses keperawatan (Gillies, 1994).

Dokumentasi dalam keperawatan sangat diperlukan dan memegang peranan penting terhadap segala macam tuntutan masyarakat yang semakin kritis, dan mempengaruhi kesadaran masyarakat akan hak-haknya dari suatu unit kesehatan. Walaupun demikian, tetapi pada kenyataannyakelengkapan pengisian dokumen masih kurang perhatian sehingga masihbanyak dokumen asuhan keperawatan yang isinya belum lengkap.

Proses keperawatan mengandung unsurunsur yang bermanfaat bagi perawat dan klien. Perawat dan klien membutuhkan proses asuhan keperawatan, merencanakan, melaksanakan, dan menilai hasil dari asuhan keperawatan. Semua itu memerlukan pendokumentasian sehingga perawat mendapatkan data klien dengan sistematis. Dokumentasi merupakan salah satu sarana komunikasi antar petugas kesehatan dalam rangka pemulihan kesehatan klien. Perawat bertanggung jawab dan bertanggung gugat dalam pencatatan tindakan keperawatan. Tanpa dokumentasi yang benar dan jelas, kegiatan pelayanan keperawatan yang telah dilaksanakan oleh seorang perawat tidak dapat dipertanggungjawabkan dalam upaya 
peningkatan mutu pelayanan keperawatan dan perbaikan status kesehatan klien. Menurut Brian Gugerty, et all dalam Challenges and Opportunities in Documentation of the Nursing Care of Patients Report of the Maryland Nursing Documentation Work Group (2007), perawat setiap harinya dalam melakukan rutinitas menghabiskan $15-25 \%$ waktunya digunakan untuk mendokumentasikan asuhan keperawatan. Tetapi perawat menganggap bahwa dokumentasi tidak penting atau berlebih-lebihan, sehingga sebagian besarwaktunya dipakai untuk melakukan tindakan keperawatan secara langsung kepada pasien. Handayaningsih (2007) menyebutkan bahwa standart dokumentasi menjadi hal yang penting dalam setiap tindakan keperawatan, namun hal ini kadang tidak disadari oleh perawat.

\section{PEMBAHASAN}

\section{Definisi POR(Problem Oriented Record)}

Tenaga perawat sebagai salah satu tenaga yang mempunyai kontribusi besar bagi pelayanan kesehatan, mempunyai peranan penting untuk meningkatkan mutu pelayanan kesehatan. Dalam upaya meningkatkan mutu pelayanan kesehatan, seorang perawat harus mampu melaksanakan asuhan keperawatan sesuai standar, yaitu dari mulai pengkajian sampai dengan evaluasi dan yang sangat penting adalah disertai dengan sistem pendokumentasian yang baik. Dokumentasi keperawatan adalah bagian yang penting dari dokumentasi klinis. Oleh karenanya diperlukan pembahasan mengenai macammacam pendokumentasian keperawatan. Problem Orientad Record (POR) adalah suatu model pendokumentasian yang memusatkan data tentang klien dan di dokumentasikan dan di susun menurut masalah klien.Sistem dokumentasi jenis ini mengintegrasikan data mengenai masalah yang di kumpulkan oleh dokter,perawat atau tenaga kesehatan lainnya dalam memberikan layanan kepada klien.

\section{Pendokumentasian pada Model POR (Problem Oriented Record)}

1) Data Dasar

Data yang berisi semua informasi yang telah dikaji dari klien ketika pertama kali masuk rumah sakit. Data dasar mencakup pengkajian keperawatan, riwayat penyakit / kesehatan, pemerikasaan fisik, pengkajian ahli gizi dan hasil laboratorium. Data dasar yang telah terkumpul selanjutkannya digunakan sebagai sarana mengidentifikasi masalah klien. Daftar Masalah

2) Daftar masalah

Berisi tentang masalah yang telah teridentifikasi dari data dasar. 
Selanjutnya masalah disusun secara kronologis sesuai tanggal identifikasi masalah. Daftar masalah ditulis pertama kali oleh tenaga kesehatan yang pertama bertemu dengan klien atau orang yang diberi tanggung jawab. Daftar masalah ini dapat mencakup masalah fisiologi, psikologis, sosiokultural, spiritual, tumbuh kembang, ekonomi dan lingkungan.Daftar ini berada pada bagian depan status klien dan tiap masalah diberi tanggal, nomor, dirumuskan dan dicantumkan nama orang yang menemukan masalah tersebut.

3) Daftar Awal Rencana Asuhan

Rencana asuhan ditulis oleh tenaga yang menyusun daftar masalah. Dokter menulis instruksinya, sedang perawat menulis instruksi keperawatan atau rencana asuhan keperawatan.

4) Perencanaan Awal

5) Diagnostik-dokter

Dalam diagnosis dokter,dokter mengidentifikasikan apa pengkajian diagnostik yang

perlu dilakukan terlebih dahulu. Juga menetapkan prioritas untuk mencegah duplikasi tindakan dan memindah pemenuhan kebutuhan klien. Koordinasi pemeriksaan untuk menegakkan diagnostik sangat penting.
6) Usulan terapi-dokter

Dalam usulan terapi dokter,dokter mengintruksikan terapi khusus berdasarkan masalah.Termasuk pengobatan, kegiatan yang tidak boleh dilakukan, diit penanganan secara khusus, observasi yang harus dilakukan. Jika masalah awal diagnosa keperawatan, perawat dapat menyusun urutan usulan tindakan asuhan keperawatan.

7) Pendidikan klien-diidentifikasi

Kebutuhan pendidikan klien bertujuan jangka panjang. Team kesehatan mengidentifikasi serius informasi atau ketrampilan yang diperlukan oleh klien untuk beradaptasi terhadap masalah yang berkaitan dengan kesehatan.

\section{Keuntungan Dan Kerugian}

\section{Keuntungan:}

Terstruktur karena informasi konsisten

Mencakup semua proses perawatan

Merupakan catatan terintegrasi dengan medik

Mudah dipakai untuk mengendalikan mutu

\section{Kekurangan:}

Menekankan pada masalah dan ketidakstabian dapat menghasilkan suatu pendekatan secara negatif terhadap pengobatan/tindakan.

Sistem ini setelah digunakan apabila dapftar tidak dimulai/tidak 
berkesinambungan/diperbarui terus menerus belum disetujui/tidak ada batas waktu untuk evaluasi dan strategi untuk follow up belum disepakati.

Perawatan mungkin tidak tercatat bila tidak ada flow sheet.

Bentuk SOAPIER mungkin mengulang pencatatan yang lain apabila perkembangan itu lambat dan sering ada evaluasi

Hal-hal yang diperlukan pada pencatatan pemulangan klien adalah:

a. Uraian mengenai intervensi kebidanan yang akan diberikan kepada klien.

b. Uraian informasi yang telah disampaikan kepada klien.

c. Uraian mengenai keadaan klien.

d. Penjelasan tantang keterlibatan keluarga dalam asuhan kebidanan.

e. Uraian mengenai sumber daya yang diperlukan dirumah.

f. Informasi untuk klien, mencakup:

g. Penggunaan bahasa yang jelas dan mudah dipahami.

h. Penjelasan prosedur tertentu sesuai dengan yang dibutuhkan klien.

i. Identifikasi tindakan pencegahan yang perlu diikuti atau dilaksanakan klien ketikamelakukan asuhan kebidanan mandiri.

j. Pemeriksaan tanda dan gejala komplikasi yang perlu dilaporkan klien jika dialami klien nantinya. k. Pemberian daftar nama dan nomor telpon tenaga kesehatan yang bisa dihubungi klien

\section{PENUTUP}

\section{Kesimpulan}

Sebelum dilakukan penerapan model dokumentasi asuhan keperawatan Problem Oriented Record (POR) kinerja perawatdalam kategori tidak baik, karena kelengkapan dokumentasinya mencapai 83,58 \% (masih dibawah standar Depkes). Setelah dilakukan penerapan model dokumentasi asuhan keperawatan POR kinerja perawat dalam kategori baik(sesuai standar Depkes). Asuhan keperawatan di Rumah Sakit dengan penerapan model dokumentasi POR, kinerja perawat menjadi lebih baik dalam pendokumentasian asuhan keperawatan.

\section{Saran}

1. Bagi Rumah Sakit

Disarankan untuk menerapkan model dokumentasi asuhan keperawatan Problem Oriented Record (POR), karena model dokumentasi ini mempunyai pengaruh terhahadap kinerja perawat dalam pendokumentasian asuhan keperawatan.

2. Bagi Perawat 
Pentingnya pelaksanaan dokumentasi keperawatan yang sesuai dengan standar dokumentasi profesi keperawatan, karena dokumentasi dalam keperawatan sangat diperlukan dan memegang peranan penting terhadap segala macam tuntutan masyarakat yang semakin kritis.

\section{Bagi Peneliti}

Perlunya dilakukan penelitian lebih lanjut dengan sampel yang lebih besar dan varibel yang lain untuk pengembangan model dokumentasi asuhan keperawatan.

\section{DAFTAR PUSTAKA}

Ardenny, A., \& Hirzal, H. (2016). Efektivitas Format Pendokumentasian

Keperawatan Model Problem Oriented Record (POR) terhadap Kemudahan Penggunaannya oleh Perawat di Rawat Jalan RSUD Petala Bumi Pekanbaru. Jurnal Kesehatan, 7(3), 366-376.
Churin'in. Gustomi, Mono Pratiko. (2013). Penerapan Model Dokumentasi Asuhan Keperawatan Problem Oriented Record (Por) Terhadap Kinerja Perawa.journals of ners communitiy.6(3). 150-157).

Koerniawan, D., Daeli, N. E., \& Srimiyati, S. (2020). Aplikasi Standar Proses Keperawatan: Diagnosis, Outcome, dan Intervensi pada Asuhan Keperawatan. Jurnal Keperawatan Silampari,3(2), 739-751.

Nazvia, N., Loekqijana, A., \& Kurniawati, J. (2014). Faktor yang mempengaruhi kepatuhan pelaksanaan SOP asuhan keperawatan di ICU-ICCU RSUD Gambiran Kota Kediri. Jurnal Kedokteran Brawijaya, 28(1), 21-25.

Nugraha, A. T. H., \& Kurniawati, T. (2012). Hubungan Persepsi Perawat Tentang Manfaat Dokumentasi Asuhan

Keperawatan Dengan Kelengkapan Dokumentasi Asuhan Keperawatan Di Ruang Rawat Inap RS Pku Muhammadiyah

Yogyakarta (Doctoral 
dissertation, STIKES'Aisyiyah Yogyakarta).

Simamora, R. (2009). Dokumentasi Proses Keperawatan.

Simamora, R. H., Purba, J. M., Bukit, E. K., \& Nurbaiti, N. (2019). Penguatan Peran Perawat Dalam Pelaksanaan Asuhan Keperawatan Melalui Pelatihan Layanan Prima. JPPM (Jurnal Pengabdian Dan Pemberdayaan

Masyarakat), 3(1), 25-31.

Tuharea, N. A., Payung, D. S., Purnawinadi, I. G., \& Rotikan, R. (2019). Sistem komputerisasi untuk pencatatan laporan asuhan keperawatan untuk mahasiswa ilmu keperawatan. Creative Information Technology Journal, 4(4), 245-253.

Wirawan, E. A., Novitasari, D., \& Wijayanti, F. (2013). Hubungan antara supervisi kepala ruang dengan pendokumentasian asuhan keperawatan di rumah sakit umum daerah ambarawa. Jurnal Manajemen Keperawatan, 1(1).

Yanti, R. I., \& Warsito, B. E. (2013). Hubungan karakteristik perawat, motivasi, dan supervisi dengan kualitas dokumentasi proses asuhan keperawatan. Jurnal

Manajemen Keperawatan, 1(2).

Yeni, F. (2014). Pengaruh Pelatihan Proses Keperawatan terhadap Dokumentasi Asuhan Keperawatan di Puskesmas Kabupaten Agam Propinsi Sumatera Barat. NERS Jurnal Keperawatan, 10(1), 24-31.

Yudiernawati, A., Setyosari, P., Degeng, I. N. S., \& Rudianto, A. (2015). Pengaruh Strategi Pembelajaran dan Gaya Kognitif terhadap Prestasi Belajar Aplikasi Proses Keperawatan pada Pembelajaran Klinik Keperawatan. Jurnal

Pendidikan Humaniora (JPH), 3(1), 31-40. 